\title{
A 3-year field study to assess winter cover crops as nitrogen sources for an organic maize crop in Mediterranean Portugal
}

\author{
Adelaide Perdigão $^{\mathrm{a}, \mathrm{b}, \mathrm{c}, *}$, José L.S. Pereira ${ }^{\mathrm{a}, \mathrm{b}}$, Nuno Moreira ${ }^{\mathrm{b}}$, Henrique Trindade ${ }^{\mathrm{b}}$, \\ João Coutinho ${ }^{\mathrm{d}}$ \\ ${ }^{a}$ Agrarian School of Viseu, Polytechnic Institute of Viseu, Quinta da Alagoa, 3500-606, Viseu, Portugal \\ ${ }^{\mathrm{b}}$ Centre for the Research and Technology of Agro-Environmental and Biological Sciences (CITAB), University of Trás-os-Montes and Alto Douro, Quinta de Prados, \\ 5000-801, Vila Real, Portugal \\ ${ }^{\mathrm{c}}$ CERNAS-IPV Research Centre, Polytechnic Institute of Viseu, Campus Politécnico, Repeses, 3504-510, Viseu, Portugal \\ ${ }^{\mathrm{d}}$ Chemistry Centre, University of Trás-os-Montes and Alto Douro, Quinta de Prados, 5000-801, Vila Real, Portugal
}

\section{A R T I C L E I N F O}

\section{Keywords:}

Balansa clover

Green manures

Maize yield

Yellow lupin

Sowing date

\begin{abstract}
A B S T R A C T
Current environmental concerns, the rising economic and environmental costs of mineral fertilizers and the need to respond to the limitations of $\mathrm{N}$ fertilization in organic farming motivate the search for alternative sources of $\mathrm{N}$ in maize cropping. Forage legumes used as winter cover crops may improve soil $\mathrm{N}$ fertility and offer benefits to the environment. The aim of this study was to examine the effects, in a factorial field experiment, of two sowing dates (SD) and nine different cover crop treatments (balansa clover, crimson clover, gland clover, arrowleaf clover, French serradella, yellow lupin, Italian ryegrass, a cover mixture and a weedy fallow) as a potential alternative $\mathrm{N}$ source in an organically managed maize crop. The experiment was conducted at Viseu (Portugal) for three years (2007/2008, 2008/2009 and 2011/12), in the same field. Results showed that maize grain yield was not influenced by cover crop species but was affected by SD and the higher dry matter (DM) aboveground biomass production was observed in early SD $\left(6.1 \mathrm{t} \mathrm{ha}^{-1}\right)$. The cover crops revealed their importance in maize $\mathrm{N}$ uptake: yellow lupin of earlier SD had the highest $\mathrm{N}$ uptake $\left(83.6 \mathrm{~kg} \mathrm{~N} \mathrm{ha}^{-1}\right.$ ), but this was not significantly different from balansa clover $\left(83.2 \mathrm{~kg} \mathrm{~N} \mathrm{ha}^{-1}\right.$ ). Ryegrass was the most efficient in depleting soil mineral $\mathrm{N}$ but values were just significantly lower than yellow lupin.

Lupin was the least efficient, leaving more mineral $\mathrm{N}$ in the soil than the others cover crops, immediately before the period when the risk of leaching is high. It was concluded that, under the edaphoclimatic conditions tested, most of the tested cover crops were efficient in supplying $\mathrm{N}$ to maize, and balansa clover had the best performance.
\end{abstract}

\section{Introduction}

One of the major challenges of modern agriculture is to develop production systems that improve yields in sustainable ways, seeking efficiency of inputs (Breda et al., 2020). Current environmental concerns lead to the search for strategies to maximize the efficiency of nitrogen (N) fertilization in maize crop (Kramberger et al., 2009; Setiyono et al., 2011; Ciampitti and Vyn, 2014), because under Mediterranean conditions irrigated maize crops are often associated with the risk of nitrate pollution (Salmerón et al., 2011). The excess $\mathrm{N}$ application is a threat to the environment (Raza et al., 2019) and potentially also to our health (Sandhu et al., 2019).
The introduction of cover crops in the rotation of this main crop, during the fall when the soil would otherwise be a fallow, i.e. bare soil, has changed conventional European practices, improving management in crop rotations (Kramberger et al., 2009) by reducing the input of synthetic fertilizers. There are several advantages of using cover crops: they can increase water holding capacity, soil porosity, aggregate stability (Abdalla et al., 2019), reduce erosion (Fan et al., 2020), fix atmospheric nitrogen, reduce nitrate leaching, improve soil health and should mitigate greenhouse gas-based climate change (Kaye and Quemada, 2017) and they can be used for weed suppression in organic farming (Akbari et al., 2019; Komainda et al., 2016; Soti and Racelis, 2020).

\footnotetext{
* Corresponding author at: Agrarian School of Viseu, Polytechnic Institute of Viseu, Quinta da Alagoa, 3500-606, Viseu, Portugal.

E-mail address: aperdigao25@gmail.com (A. Perdigão).
} 
Some cover crops may reduce the risk of nitrate leaching (Alonso-Ayuso et al., 2018; Rose et al., 2019) while maintaining maize productivity (Salmerón et al., 2011; Marcillo et al., 2019). Therefore, use of cover crops is a choice environmentally and economically viable for maize production (da Silva et al., 2020). However, according to the same authors, this is not a usual practice in low rainfall semi-arid conditions. Alonso-Ayuso et al. (2018) justify this disuse stating that cover crops are suspected of competing for water and nutrients with the cash crop.

In environmental terms, it is important to efficiently exploit available $\mathrm{N}$, that is, the use of all available $\mathrm{N}$ by the decomposition of cover crops during the maize growth phase (Kramberger et al., 2014). Therefore, understanding the impact of different forage legumes on the $\mathrm{N}$ content and yield of the main crop is important to improve the efficiency of $\mathrm{N}$ fertilization in annual crop rotations (Rasmussen et al., 2012). An important reason for the variation of the effects of different cover crops on the supply of $\mathrm{N}$ to maize crop is the different dynamics of net $\mathrm{N}$ mineralization/immobilization during residue decomposition (Kramberger et al., 2014). Since maize is a N demanding crop and N fertilization is limited in organic farming, there is need to study alternative sources of N (Hanly and Gregg, 2004), namely the use of new legumes (Perdigão et al., 2012). Also, the effect of cover crops on maize performance differ, depending on a range of factors such as sowing date, weather conditions and species choice (Fan et al., 2020). Sowing date of cover crops is so important that, according to the same authors, the Dutch government has stipulated a new legislation in 2019 that states that after maize cultivation on sand and loess soils a cover crop must be sown by 1 October (Fan et al., 2020). To date, to our knowledge, no extensive evaluation of different cover crops species with varying sowing date has been made for maize production in the Mediterranean conditions.

The objective of this study was to evaluate the effect of different cover crop species established at two different sowing dates for improvement of $\mathrm{N}$ cycling to increase organic maize productivity in Mediterranean conditions.

\section{Material and methods}

\subsection{Soil and site description}

A field experiment was carried out in central Portugal (Viseu, Portugal; latitude: $40.641789^{\circ}$, longitude: $-8.655840^{\circ}$ ), during the years $2007 / 2008,2008 / 2009$ and $2011 / 2012$. The long term yearly mean air temperature in the region is $14.2^{\circ} \mathrm{C}$, the monthly mean air minimum is $6.9{ }^{\circ} \mathrm{C}$ in January, and the maximum is $21.4{ }^{\circ} \mathrm{C}$ in July. The long-term average (thirty years average) annual rainfall in the area is $1200 \mathrm{~mm}$. The highest average monthly precipitation is recorded in December, with $203.4 \mathrm{~mm}$. The average monthly temperatures and amounts of precipitation during the experiment are presented in Table 1. It was found that there were heterogeneous years in climatic conditions, mainly in accumulated precipitation. In December 2007/08 it hardly rained when compared to the other years. In February there are also notable differences, with the last year of testing with very low rainfall values compared to the years $2007 / 08$ and $2008 / 09$. Annual precipitation in these years was about $40-50 \%$ less than the long-term average.

The soil used in this study was classified as a Distric Fluvisol (IUSS Working Group W.R.B., 2006), with a sandy-loam texture (44.2\% coarse sand, $24.0 \%$ fine sand, $16.3 \%$ silt and $15.4 \%$ clay). The physico-chemical properties of the soil were: bulk density: $0.9 \mathrm{~g} \mathrm{~cm}^{-3}$, $\mathrm{pH}\left(\mathrm{H}_{2} \mathrm{O}\right): 6.0$, electrical conductivity: $0.02 \mathrm{mS} \mathrm{cm}^{-1}$, water holding capacity (WHC) at $\mathrm{pF} 2.0,38.4 \%(\mathrm{w} / \mathrm{w})$, total C: $15.60 \mathrm{~g}[\mathrm{~kg} \text { dry soil }]^{-1}$, total $\mathrm{N}$ : $1.84 \mathrm{~g}[\mathrm{~kg} \text { dry soil }]^{-1}$. Total $\mathrm{C}$ and total $\mathrm{N}$ were determined using an elemental analyzer by Dumas (Primac SC, Skalar, Breda, NL) and near infrared detection (SanPlus, Skalar, Breda, NL), respectively.

\subsection{Experimental design}

A three-year factorial field experiment was conducted considering nine cover crops treatments at two sowing dates, with four replications: balansa clover (Trifolium michelianum Savi.), crimson clover (Trifolium incarnatum L.), gland clover (Trifolium glanduliferum Boiss.), arrowleaf clover (Trifolium vesiculosum Savi), French serradella (Ornithopus sativus Brot.), yellow lupin (Lupinus luteus L.), Italian ryegrass (Lolium multiflorum Lam.), a cover crop mixture of ryegrass and balansa clover and weeds (permanent resident vegetation) as a control treatment. The experiment was conducted in a randomized complete spilt-plot design, with sowing dates of cover crops as main plots (Table 2) and different cover crop species as subplots (subplot size $3 \mathrm{~m} \times 5 \mathrm{~m}$ ). The experiment was performed in the same plots year after year. Previously the field had spontaneous vegetation.

The cover crops species were sown by hand and seeding rates are presented in Table 3 . Seeds in the mixture were completely mixed before sowing. The cover crops were not fertilized. No weed control was performed.

At the end of April, at full bloom, cover crops were shredded and

Table 2

Characteristics of some key agronomic management practices in the experiments.

\begin{tabular}{llll}
\hline & $2007 / 2008$ & $2008 / 2009$ & $2011 / 2012$ \\
\hline $1^{\text {st }}$ Sowing date & $21 / 09 / 2007$ & $25 / 09 / 2008$ & $15 / 10 / 2011$ \\
$2^{\text {nd }}$ Sowing date & $27 / 10 / 2007$ & $25 / 10 / 2008$ & $29 / 11 / 2011$ \\
Cover crops incorporation in soil & $08 / 05 / 2008$ & $06 / 05 / 2009$ & $16 / 05 / 2012$ \\
Maize sowing & $09 / 05 / 2008$ & $08 / 05 / 2009$ & $31 / 05 / 2012$ \\
Irrigation beginning & $25 / 06 / 2008$ & $26 / 06 / 2009$ & $08 / 07 / 2012$ \\
Total amount of water irrigation & $550 \mathrm{~mm}$ & $500 \mathrm{~mm}$ & $400 \mathrm{~mm}$ \\
Maize harvesting & $03 / 09 / 2008$ & $06 / 09 / 2009$ & $15 / 09 / 2012$ \\
\hline
\end{tabular}

Table 1

Total monthly air temperature and precipitation and their long term average during experiment.

\begin{tabular}{|c|c|c|c|c|c|c|c|c|}
\hline \multirow[t]{2}{*}{ Month } & \multicolumn{3}{|c|}{ Temperature $\left({ }^{\circ} \mathrm{C}\right)$} & \multirow[t]{2}{*}{$\mathrm{LTA}^{\mathrm{a}}$} & \multicolumn{3}{|c|}{ Precipitation (mm) } & \multirow[t]{2}{*}{$\mathrm{LTA}^{\mathrm{a}}$} \\
\hline & $2007 / 08$ & $2008 / 09$ & $2011 / 12$ & & $2007 / 08$ & $2008 / 09$ & $2011 / 12$ & \\
\hline September & 19.6 & 18.0 & 18.0 & 18.8 & 5.5 & 42.6 & 55.1 & 57.0 \\
\hline October & 15.3 & 14.1 & 17.5 & 14.2 & 30.2 & 37.0 & 74.5 & 133.2 \\
\hline November & 10.5 & 8.0 & 7.0 & 10.2 & 97.0 & 60.3 & 146.0 & 135.9 \\
\hline December & 7.6 & 7.1 & 6.9 & 8.1 & 10.0 & 107.4 & 100.0 & 195.4 \\
\hline January & 8.9 & 6.9 & 6.7 & 6.9 & 139.1 & 135.0 & 19.3 & 155.7 \\
\hline February & 11.0 & 8.3 & 6.3 & 8.4 & 48.5 & 104.0 & 1.5 & 133.6 \\
\hline March & 9.9 & 12.9 & 12.3 & 10.3 & 28.3 & 19.0 & 18.8 & 74.8 \\
\hline April & 12.8 & 10.3 & 9.7 & 11.5 & 157.1 & 82.8 & 137.7 & 105.2 \\
\hline May & 13.6 & 15.3 & 16.2 & 14.3 & 79.3 & 25.5 & 130.1 & 95.9 \\
\hline June & 19.3 & 17.9 & 18.4 & 18.4 & 0 & 22.1 & 17.3 & 46.1 \\
\hline July & 20.6 & 19.3 & 20.6 & 21.4 & 0 & 15.0 & 2.0 & 19.2 \\
\hline August & 20.4 & 23.0 & 20.4 & 21.1 & 2.5 & 0 & 14.5 & 17.9 \\
\hline
\end{tabular}

a Long term averages. 
Table 3

Cover crop species studied and seeding rates.

\begin{tabular}{lll}
\hline Cover Crop & Seeding rate & Seedsm \\
\hline Balansa clover (BC) & $10 \mathrm{~kg} \mathrm{ha}^{-1}$ & 1786 \\
Crimson clover (CC) & $20 \mathrm{~kg} \mathrm{ha}^{-1}$ & 211 \\
Gland clover (GC) & $10 \mathrm{~kg} \mathrm{ha}^{-1}$ & 1887 \\
Arrowleaf clover (AC) & $10 \mathrm{~kg} \mathrm{ha}^{-1}$ & 667 \\
French serradella (FS) & $20 \mathrm{~kg} \mathrm{ha}^{-1}$ & 227 \\
Yellow lupin (YL) & $5.6 \mathrm{~kg} \mathrm{ha}^{-1}$ & 60 \\
Ryegrass (R) & $30 \mathrm{~kg} \mathrm{ha}^{-1}$ & 341 \\
Mixture of ryegrass and balansa & $60 \%$ of each & $60 \%$ of each \\
clover (M) & monoculture & monoculture \\
\hline
\end{tabular}

incorporated into the soil, with a disc harrow (100 mm approximately) just before seeding the maize crop (Table 2). Local maize was sown with a low precision hand seeder at density of 90,000 seeds ha $^{-1}$ in May. Local maize is a variety obtained from local farmers, well adapted to local conditions and less demanding in water and fertilizers than commercial cultivars, although also less productive than these. Maize irrigation (Table 2) started in second half of June/early July by sprinkler watering in years 2008 and 2009 and drip watering in the last year of the experiment. Irrigation was stopped at the end of August. Approximately $500 \mathrm{~mm}$ of water were applied each year. About $50 \mathrm{~mm}$ were applied per week separated into 3-4 irrigation events. In none of experiments, maize received any organic or mineral fertilizers.

The control of weeds in the maize crop conducted manually. Each year, maize was harvested in the first half of September. All aboveground maize residues were removed from the plots.

\subsection{Soil and plant analysis}

Soil mineral N (Nmin) was determined in the 0-200 mm soil-depth. Soil was sampled each year before cover crops seeding and at maize sowing. Six sub-samples per plot were taken, were mixed, sieved $(2 \mathrm{~mm})$ and frozen $\left(-18^{\circ} \mathrm{C}\right)$. Another soil sample was taken per plot and dried at $105{ }^{\circ} \mathrm{C}$ to constant weight for gravimetric water content determination. Later, the soil samples frozen were analyzed for $\mathrm{NH}_{4}^{+}-\mathrm{N}$ and $\mathrm{NO}_{3}^{-}-\mathrm{N}$ by $2 \mathrm{M} \mathrm{KCl}$ using an elemental analyzer by Dumas (Primacs SC, Skalar, Breda, NL) and near infrared detection (SanPlus, Skalar, Breda, NL).

At the end of April, the aboveground biomass of the cover crops was obtained by cutting the crop to a height of $5 \mathrm{~cm}$ from $0.25 \mathrm{~m}^{2}$ in each subplot and weighing it. The yield of maize was obtained at the end of the growing season by choosing two central lines of each subplot, cutting to a stubble height of $10 \mathrm{~cm}$ and weighing the whole aboveground mass and separately, the yield of grain. The aliquot subsamples of the cover crops and the maize were used to determine dry matter yield (DM) by drying to a constant weight at $65^{\circ} \mathrm{C}$ in a forced-draught oven. The amount of DM and $\mathrm{N}$ uptake of maize was determined in relation to grain and total aboveground biomass. The $\mathrm{N}$ concentration in the yields was determined by Kjeldahl method. Nitrogen uptake was determined by multiplying dry matter weight (aboveground biomass) by $\mathrm{N}$ concentration.

The critical $\mathrm{N}$ concentration $(\mathrm{CNc})$ in the maize, i.e. the plant $\mathrm{N}$ concentration needed to reach maximum growth, was calculated according to the formula used by Lemaire et al. (2004) and Kramberger et al. (2014), where CNc $\left(\mathrm{kg} \mathrm{N} \mathrm{ha}^{-1}\right)=34\left(\text { maize yield }\left(\mathrm{kg} \mathrm{ha}^{-1}\right)\right)^{0.63}$. To find out how much of the critical $\mathrm{N}$ concentration was satisfied by the $\mathrm{N}$ provided by cover crops, the $\% \mathrm{CNc}$ was calculated as a function of the $\mathrm{N}$ uptake in the aboveground biomass of cover crops.

For calculating the budget of the apparent remaining $\mathrm{N}$ in the soil (ARNS), the modified formula of Kramberger et al. (2009; 2014) was used: ARNS $\left(\mathrm{kg} \mathrm{N} \mathrm{ha}^{-1}\right)=(\mathrm{N}$ in cover crops residues + soil $\mathrm{N}$ min at the time of maize sowing $+\mathrm{N}$ added with maize fertilization) $-\mathrm{N}$ taken up in the aboveground maize yield. In the present study, as no fertilizer was used, the fertilizer $\mathrm{N}$ was considered null.

\subsection{Statistical analysis}

Data were analyzed using analysis of variance ("General AOV") of STATISTIX 7.0 software program (Tallahassee, FL, USA). The normality of the distribution of the studied traits was tested using the Shapiro-Wilk normality test. A General AOV was performed to determine the effects of years, sowing date, cover crops, and all interactions. Year, sowing date, block and cover crops were treated as fixed. Means were separated by Bonferroni's multiple range tests for the factors and interactions. Statistical significance was evaluated at $p<0.05$.

\section{Results}

\subsection{Cover crops}

As can be observed in Tables 4 and 5 , the cover crop species significantly affected $(p<0.05)$ the biomass fresh weight and $\mathrm{N}$ uptake. Both sowing dates of the second year of the experiment had $\mathrm{N}$ uptake values $\left(173 \mathrm{~kg} \mathrm{~N} \mathrm{ha}^{-1}\right.$ and $166 \mathrm{~kg} \mathrm{~N} \mathrm{ha}^{-1}$ ) significantly higher $(p<0.05)$ than the first and third year (Fig. 1). Significant differences $(p<0.05)$ were found between the $\mathrm{N}$ uptake at the first sowing date $\left(42 \mathrm{~kg} \mathrm{~N} \mathrm{ha}^{-1}\right)$ and the second sowing date $\left(94 \mathrm{~kg} \mathrm{~N} \mathrm{ha}^{-1}\right.$ ) of the first year of testing (Tables 4 and 5). In the third year of testing no significant differences ( $p>$ 0.05) were observed between sowing dates (Table 4).

Among cover crop species, yellow lupin had the highest $\mathrm{N}$ uptake (148 $\mathrm{kg} \mathrm{N} \mathrm{ha}^{-1}$ ) (Table 5). Only N uptake by crimson clover (114 kg N $\mathrm{ha}^{-1}$ ) and arrowleaf clover (113 $\mathrm{kg} \mathrm{N} \mathrm{ha}^{-1}$ ) did not differ significantly ( $p$ $>0.05$ ) from $\mathrm{N}$ uptake by yellow lupin. The ryegrass was the treatment with the lowest $\mathrm{N}$ uptake $\left(68 \mathrm{~kg} \mathrm{~N} \mathrm{ha}^{-1}\right)$, being significantly lower $(p<$ 0.05 ) than the three mentioned above. The value related to the mixture did not differ significantly $(p>0.05)$ from balansa clover (105 kg N $\mathrm{ha}^{-1}$ ) or ryegrass and presented an intermediate value $\left(95 \mathrm{~kg} \mathrm{~N} \mathrm{ha}^{-1}\right)$. Comparing the $\mathrm{N}$ uptake value in the yellow lupin with ryegrass and spontaneous vegetation (or weeds), we found an $\mathrm{N}$ uptake increase of $116 \%$ and $90 \%$, respectively (Table 5).

\subsection{Maize crop}

\subsubsection{Dry matter yield}

The Table 4 shows significant differences $(p<0.05)$ were found between treatments and interactions. Regarding the year, it was found that the production of maize grain yield varied significantly $(p<0.05)$ between the three years of study. The highest yield was obtained in the second year of the experiment with $2.8 \mathrm{Mg} \mathrm{ha}^{-1}$, followed by the firstyear yield at $2.2 \mathrm{Mg} \mathrm{ha}^{-1}$. The lowest value was recorded in the third year of the test at $1.3 \mathrm{Mg} \mathrm{ha}^{-1}$ (Table 6).

Maize grain yield was higher in the treatment from the first sowing date of balansa clover $\left(2.7 \mathrm{Mg} \mathrm{ha}^{-1}\right)$ and the lowest value was observed in the treatment from the second sowing date of gland clover (1.3 Mg ha ${ }^{-1}$ ) (Table 6). There were no significant differences $(p>0.05)$ between the mixture and the treatments that comprise it. There were also no significant differences $(p>0.05)$ between cover crops and weeds. For the first SD no differences were observed between cover crops. In second $\mathrm{SD}$ the highest $\mathrm{DM}$ was observed in ryegrass and similar after balansa clover (2.3 $\mathrm{Mg} \mathrm{ha}^{-1}$ and $2.0 \mathrm{Mg} \mathrm{ha}^{-1}$, respectively). The lowest DM was found after gland clover and French serradella $\left(1.3 \mathrm{Mg} \mathrm{ha}^{-1}\right.$ and $1.4 \mathrm{Mg}$ $\mathrm{ha}^{-1}$, respectively). The treatments from the first SD induced a greater accumulation of DM in maize (Table 6).

The highest DM production of aboveground biomass was verified in the treatment from the gland clover in the first year of test and first sowing date, with a DM yield of $9.1 \mathrm{Mg} \mathrm{ha}^{-1}$ (Table 7). The lowest yield was observed in the treatment from the mixture in third year of trial and first sowing date $\left(3.3 \mathrm{Mg} \mathrm{ha}^{-1}\right.$ ) (Table 7$)$. There were no significant differences $(p>0.05)$ between the mixture and the treatments that comprise it. No significant differences were observed $(p>0.05)$ between cover crops in each sowing date (Table 7). 
Table 4

Analysis of variance tests of fixed effects and their interactions on dependent variables evaluated.

\begin{tabular}{|c|c|c|c|c|c|c|c|c|}
\hline \multirow{2}{*}{$\begin{array}{l}\text { Parameters } \\
\text { Cover Crops (CC) }\end{array}$} & \multicolumn{2}{|c|}{ Cover Crops } & \multicolumn{2}{|l|}{ Grain } & \multicolumn{2}{|c|}{$\begin{array}{l}\text { Total aboveground } \\
\text { biomass }\end{array}$} & $\%$ Critical N concentration & \multirow[t]{2}{*}{ Apparent remaining $\mathrm{N}$ in the soil (ARNS) } \\
\hline & $\begin{array}{l}\text { N uptake } \\
* * *\end{array}$ & $\begin{array}{l}\text { Fresh biomass } \\
* * *\end{array}$ & $\begin{array}{l}\text { DM yield } \\
n s\end{array}$ & $\begin{array}{l}\text { N uptake } \\
*\end{array}$ & $\begin{array}{l}\text { DM yield } \\
n s\end{array}$ & $\begin{array}{l}\mathrm{N} \text { uptake } \\
n s\end{array}$ & * & \\
\hline Sowing date (SD) & $n s$ & $n s$ & ** & * & * & $n s$ & $n s$ & $n s$ \\
\hline $\operatorname{Year}(Y)$ & $* * *$ & $* * *$ & $* * *$ & $* * *$ & $* *$ & $* * *$ & $* * *$ & $* * *$ \\
\hline$C C \times S D$ & $n s$ & $n s$ & $*$ & $* *$ & $n s$ & $* *$ & * & $n s$ \\
\hline$C C \times Y$ & $n s$ & $n s$ & $n s$ & $n s$ & $n s$ & $n s$ & * & $n s$ \\
\hline$S D \times Y$ & $* * *$ & $* * *$ & $n s$ & $n s$ & $n s$ & $n s$ & $n s$ & $*$ \\
\hline$S D \times Y \times C C$ & $n s$ & $n s$ & $n s$ & $n s$ & $*$ & $n s$ & $n s$ & $n s$ \\
\hline
\end{tabular}

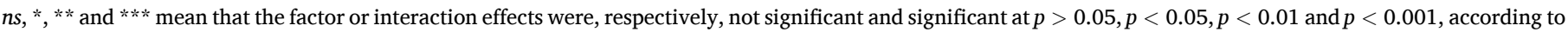
the T Bonferroni's test, respectively.

Table 5

Average $\mathrm{N}$ uptake in aerial biomass of cover crops at the end of the growing season $(n=4)$.

\begin{tabular}{lll}
\hline Cover crops & $\begin{array}{l}\text { Fresh biomass (Mg } \\
\left.\text { ha }{ }^{-1}\right)\end{array}$ & $\begin{array}{l}\mathrm{N} \mathrm{uptake}(\mathrm{kg} \\
\left.\mathrm{ha}^{-1}\right)\end{array}$ \\
\hline $\begin{array}{l}\text { Ryegrass (R) } \\
\text { Mixture of ryegrass and balansa }\end{array}$ & $19.9^{\mathrm{bc}}$ & $68.5^{\mathrm{c}}$ \\
$\quad 21.8^{\mathrm{bc}}$ & $95.1^{\mathrm{bc}}$ \\
clover (M) & & \\
Balansa clover (BC) & $23.5^{\mathrm{ab}}$ & $105.2^{\mathrm{bc}}$ \\
Weeds (W) & $18.4^{\mathrm{bc}}$ & $84.1^{\mathrm{bc}}$ \\
Yellow lupin (YL) & $17.8^{\mathrm{c}}$ & $77.7^{\mathrm{bc}}$ \\
French serradella (FS) & $28.5^{\mathrm{a}}$ & $147.7^{\mathrm{a}}$ \\
Crimson clover (CC) & $19.5^{\mathrm{bc}}$ & $98.2^{\mathrm{bc}}$ \\
Arrowleaf clover (AC) & $21.7^{\mathrm{bc}}$ & $114.2^{\mathrm{ab}}$ \\
\hline
\end{tabular}

Treatments followed by different letter are significantly different at $p<0.05$ by Bonferroni's test.

\subsubsection{Nitrogen uptake}

Table 4 shows the results of the significant differences $(p<0.05)$ between treatments and interactions. It was in the second year of experiment that a higher $\mathrm{N}$ uptake of grain $\left(40.5 \mathrm{~kg} \mathrm{~N} \mathrm{ha}^{-1}\right)$ was observed, although this value is not significantly different $(p>0.05)$ from the value observed in the first year of experiment $\left(38.9 \mathrm{~kg} \mathrm{~N} \mathrm{ha}^{-1}\right)$. The lowest value $\left(15.5 \mathrm{~kg} \mathrm{~N} \mathrm{ha}^{-1}\right)$ was observed in the third year of the trial and was significantly lower $(p<0.05)$ than the others (Table 6).

The $\mathrm{N}$ uptake for grain ranged from $48.0 \mathrm{~kg} \mathrm{~N} \mathrm{ha}^{-1}$ in treatment of balansa clover from the first sowing date to $17.5 \mathrm{~kg} \mathrm{~N} \mathrm{ha}^{-1}$ for the treatment of gland clover from the second sowing date (Table 6). On the second sowing date balansa clover $\mathrm{N}$ uptake was significantly different $(p<0.05)$ from the yellow lupin and French serradella. No significant differences $(p>0.05)$ between cover crops were found in first SD (Table 6).

When we compared $\mathrm{N}$ uptake of the grain from clover balansa treatment with that from weeds, we observed an increase of $104 \%$ in the first sowing date and $20 \%$ in the second sowing date. Compared to the treatment after ryegrass, the observed increase in balansa clover treatment is $81 \%$ for the first date and $26 \%$ for the second sowing date. For the first sowing date, $\mathrm{N}$ uptake in mixture was intermediate between that observed after balansa clover and after ryegrass. On the second sowing date, $\mathrm{N}$ uptake after mixture was lower than that observed in the treatment after ryegrass. The $\mathrm{N}$ uptake after balansa clover was not significantly different $(p>0.05)$ from the $\mathrm{N}$ uptake after yellow lupin and the difference was reduced at the first sowing date $(0.8 \%)$, but with important differences comparatively the second sowing date (71\%).

Total aboveground $\mathrm{N}$ uptake was higher in the first year of the experiment $\left(96.0 \mathrm{~kg} \mathrm{~N} \mathrm{ha}^{-1}\right)$ and decreased during the experiment ( $64.0 \mathrm{~kg} \mathrm{~N} \mathrm{ha}^{-1}$ in the second year and $29.3 \mathrm{~kg} \mathrm{~N} \mathrm{ha}^{-1}$ in the third year), all values being significantly different $(p<0.05)$ from each other (Table 6). The $\mathrm{N}$ uptake ranged from $83.6 \mathrm{~kg} \mathrm{~N}^{-1}$ for yellow lupin at the first sowing date and $38.2 \mathrm{~kg} \mathrm{~N} \mathrm{ha}^{-1}$ to gland clover of the second sowing date (Table 6). For the first sowing date, the effect of yellow lupin and balansa clover compared to weeds resulted in increase of $\mathrm{N}$ uptake of $68 \%$. On the first sowing date, the $\mathrm{N}$ uptake of mixture was intermediate between that balansa and ryegrass, but on the second date $\mathrm{N}$ uptake of mixture was lower than ryegrass (37 \% lower).

\subsubsection{Critical $N$ concentration}

In this study we found significant differences $(p<0.05)$ among

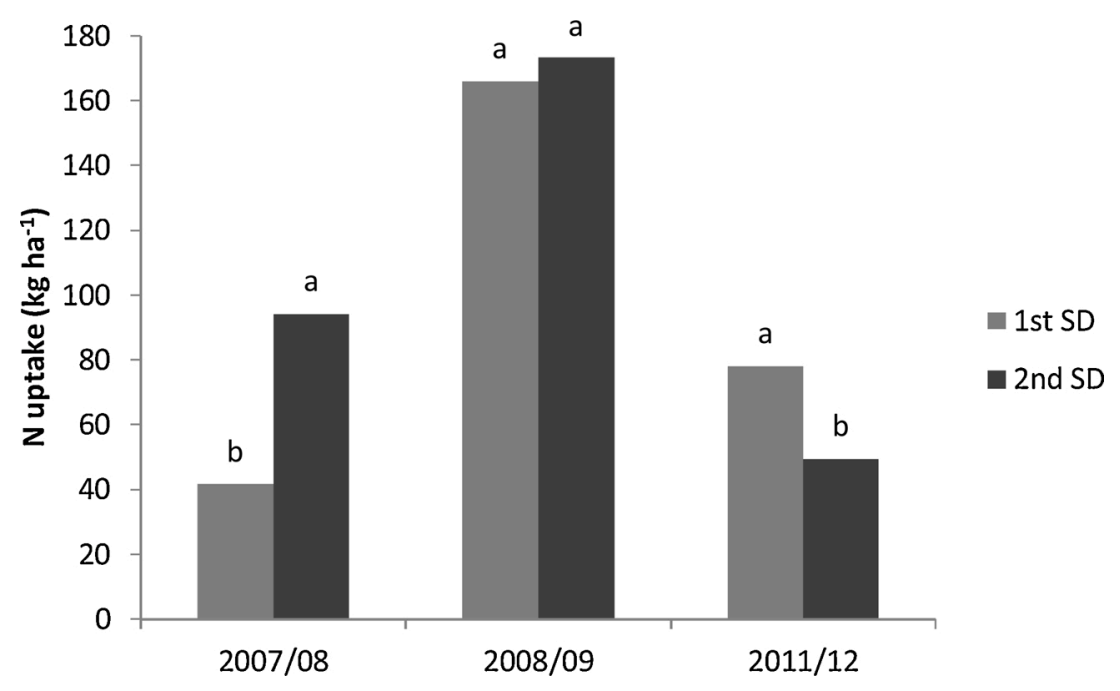

Fig. 1. Effects of year and sowing date interaction in $\mathrm{N}$ uptake of cover crops. For each year, columns followed by different letter are significantly different at $p<0.05$ by Bonferroni's test $(n=4)$. 
Table 6

Average dry matter yield of grain, aboveground biomass of the maize crop and \% of the critical $\mathrm{N}$ concentration provided by cover crops $(n=4)$.

\begin{tabular}{|c|c|c|c|c|c|c|}
\hline \multirow[t]{2}{*}{$\begin{array}{l}\text { Sowing } \\
\text { Date }\end{array}$} & \multirow[t]{2}{*}{$\begin{array}{l}\text { Cover } \\
\text { crops }\end{array}$} & \multicolumn{2}{|l|}{ Grain } & \multicolumn{2}{|c|}{$\begin{array}{l}\text { Aboveground } \\
\text { biomass }\end{array}$} & \multirow[t]{2}{*}{$\begin{array}{l}\% \text { Critical N } \\
\text { concentration }\end{array}$} \\
\hline & & $\begin{array}{l}\mathrm{DM} \\
(\mathrm{Mg} \\
\left.\mathrm{ha}^{-1}\right)\end{array}$ & $\begin{array}{l}\mathrm{N} \\
\text { uptake } \\
(\mathrm{kg} \\
\left.\mathrm{ha}^{-1}\right)\end{array}$ & $\begin{array}{l}\mathrm{DM} \\
(\mathrm{Mg} \\
\left.\mathrm{ha}^{-1}\right)\end{array}$ & $\begin{array}{l}\mathrm{N} \\
\text { uptake } \\
(\mathrm{kg} \\
\left.\mathrm{ha}^{-1}\right)\end{array}$ & \\
\hline \multirow{13}{*}{1 st SD } & $\mathrm{R}$ & $2.2^{\mathrm{a}}$ & $26.5^{\mathrm{a}}$ & $6.1^{\mathrm{a}}$ & $59.3^{\mathrm{ab}}$ & $53.1^{\mathrm{ab}}$ \\
\hline & M & $2.6^{\mathrm{a}}$ & $38.7^{\mathrm{a}}$ & $6.2^{\mathrm{a}}$ & $68.9^{\mathrm{ab}}$ & $60.0^{\mathrm{ab}}$ \\
\hline & $\mathrm{BC}$ & $2.7^{\mathrm{a}}$ & $48.0^{\mathrm{a}}$ & $6.5^{\mathrm{a}}$ & $83.2^{\mathrm{a}}$ & $70.3^{\mathrm{a}}$ \\
\hline & GC & $2.7^{\mathrm{a}}$ & $40.3^{\mathrm{a}}$ & $6.6^{\mathrm{a}}$ & $82.4^{\mathrm{a}}$ & $68.2^{\mathrm{a}}$ \\
\hline & $\mathrm{W}$ & $1.7^{\mathrm{a}}$ & $23.6^{\mathrm{a}}$ & $4.7^{\mathrm{a}}$ & $49.6^{\mathrm{ab}}$ & $51.8^{\mathrm{ab}}$ \\
\hline & YL & $2.4^{\mathrm{a}}$ & $42.7^{\mathrm{a}}$ & $6.6^{\mathrm{a}}$ & $83.6^{\mathrm{a}}$ & $69.1^{\mathrm{a}}$ \\
\hline & FS & $2.3^{\mathrm{a}}$ & $31.4^{\mathrm{a}}$ & $5.5^{\mathrm{a}}$ & $60.8^{\mathrm{ab}}$ & $60.7^{\mathrm{ab}}$ \\
\hline & $\mathrm{CC}$ & $2.3^{\mathrm{a}}$ & $37.1^{\mathrm{a}}$ & $6.0^{\mathrm{a}}$ & $64.5^{\mathrm{ab}}$ & $56.3^{\mathrm{ab}}$ \\
\hline & AC & $2.3^{\mathrm{a}}$ & $30.0^{\mathrm{a}}$ & $6.3^{\mathrm{a}}$ & $68.2^{\mathrm{ab}}$ & $57.8^{\mathrm{ab}}$ \\
\hline & $\mathrm{R}$ & $2.3^{\mathrm{a}}$ & $30.4^{\mathrm{abc}}$ & $5.9^{\mathrm{a}}$ & $66.4^{\mathrm{ab}}$ & $60.3^{\mathrm{ab}}$ \\
\hline & M & $1.6^{\mathrm{ab}}$ & $24.3^{\mathrm{abc}}$ & $4.8^{\mathrm{a}}$ & $48.4^{\mathrm{ab}}$ & $50.9^{\mathrm{ab}}$ \\
\hline & $\mathrm{BC}$ & $2.0^{\mathrm{a}}$ & $38.4^{\mathrm{a}}$ & $5.9^{\mathrm{a}}$ & $75.2^{\mathrm{ab}}$ & $70.7^{\mathrm{a}}$ \\
\hline & GC & $1.3^{\mathrm{b}}$ & $17.5^{c}$ & $4.3^{\mathrm{a}}$ & $38.2^{\mathrm{b}}$ & $45.1^{\mathrm{b}}$ \\
\hline \multirow[t]{5}{*}{2 nd SD } & $\mathrm{W}$ & $1.9^{\mathrm{ab}}$ & $32.0^{\mathrm{abc}}$ & $5.4^{\mathrm{a}}$ & $63.0^{\mathrm{ab}}$ & $62.8^{\mathrm{ab}}$ \\
\hline & YL & $1.6^{\mathrm{ab}}$ & $22.4^{\mathrm{bc}}$ & $4.8^{\mathrm{a}}$ & $52.2^{\mathrm{ab}}$ & $55.3^{\mathrm{ab}}$ \\
\hline & FS & $1.4^{\mathrm{b}}$ & $19.5^{\mathrm{bc}}$ & $5.0^{\mathrm{a}}$ & $51.1^{\mathrm{ab}}$ & $55.1^{\mathrm{ab}}$ \\
\hline & $\mathrm{CC}$ & $2.2^{\mathrm{ab}}$ & $32.7^{\mathrm{abc}}$ & $5.4^{\mathrm{a}}$ & $58.6^{\mathrm{ab}}$ & $57.5^{\mathrm{ab}}$ \\
\hline & AC & $2.1^{\mathrm{ab}}$ & $34.0^{\mathrm{ab}}$ & $5.2^{\mathrm{a}}$ & $62.4^{\mathrm{ab}}$ & $62.2^{\mathrm{ab}}$ \\
\hline
\end{tabular}

R: Ryegrass, M: Mixture of ryegrass and balansa clover, BC: Balansa clover, GC: Gland clover, W: Weeds, YL: Yellow lupin, FS: French serradella, CC: Crimson clover, AC: Arrowleaf clover.

For grain and aboveground biomass, in each sowing date, treatments followed by different letter are significantly different at $p<0.05$ by Bonferroni's test. For $\%$ critical $\mathrm{N}$ concentration wwithin column, treatments followed by different letter are significantly different at $p<0.05$ by Bonferroni's test.

treatments in the $\% \mathrm{CNc}$ (Table 4). In the year $\times$ cover crops interaction (Fig. 2) it was found that the \% CNc satisfied by cover crops ranged from over $100 \%$ for balansa clover in the first year of experiment to $26 \%$ for gland clover in the third year. Along the experiments, the $\% \mathrm{CNc}$ satisfied by cover crops decreased for all treatments.

When we examined the sowing date $\times$ cover crops interaction, the values ranged from $71 \%$ for the balansa clover of the second sowing date to $45 \%$ for the gland clover of the second sowing date (Table 6). There were no significant differences $(p>0.05)$ between the mixture and the treatments that comprise it. There were also no significant differences $(p>0.05)$ between cover crops and weeds (Table 6).

\subsection{Apparent remaining $N$ in the soil}

Apparent remaining $\mathrm{N}$ in the soil (ARNS) showed significant differences $(p<0.05)$ among treatments (Fig. 3). This ranged between $110.7 \mathrm{~kg} \mathrm{ha}^{-1}$ in second year of experiment to $-24.0 \mathrm{~kg} \mathrm{ha}^{-1}$ in first year of experiment. In the year $\times$ sowing date interaction we observed a higher ARNS in the second sowing date of the second year $(120.8 \mathrm{~kg}$ ha $^{-1}$ ) (Fig. 3). Sowing date of cover crops species did not significantly affect $(p>0.05)$ ARNS.
Nitrogen remaining in soil by cover crops ranged from $9.7 \mathrm{~kg} \mathrm{~N} \mathrm{ha}^{-1}$ to $85.0 \mathrm{~kg} \mathrm{~N} \mathrm{ha}^{-1}$, as shown in Fig. 4. The ryegrass treatment was not significantly lower $(p>0.05)$ than the rest of cover crops species except yellow lupin. It was observed that yellow lupin left more $\mathrm{N}$ in the soil at the end of the crop cycle of maize (Fig. 4).

\section{Discussion}

The introduction of leguminous species as winter cover crops for maize crop rotations is not yet a common practice in Portugal, perhaps due to the limited information available on this practice. The long period between the harvest and the new sowing of maize (from September/ October to April/May) allows the good development of cover crops, making it a possible practice under Mediterranean conditions, as stated by Salmerón et al. (2011).

For all parameters studied, significant differences $(p<0.05)$ were observed between years. These differences are due to the different climatic conditions observed in these years, especially the precipitation occurred, as temperatures were similar over the three years. Also the start of irrigation practice, the amount of water applied and the type of irrigation were different between the years of the experiment, and may even have occurred late or in insufficient quantity.

Maize grain production, which ranged from 1.3 to $2.7 \mathrm{Mg}^{-1}$, was lower than the values reported in the literature. For example, Yeganehpoor et al. (2015), using clover and vet combined with maize (grown together) in Iran, recorded grain yields of 4.1 and $3.7 \mathrm{Mg} \mathrm{ha}^{-1}$. In the study previously referred, like in the present study, there was no application of $\mathrm{N}$ in the maize sowing or during its growth/development. Very different results are reported by Kramberger et al. (2014), where grain yield ranged from $5.5 \mathrm{Mg} \mathrm{ha}^{-1}$ after ryegrass to $10.2 \mathrm{Mg} \mathrm{ha}^{-1}$ after red clover. However, in this work $\mathrm{N}$ was applied $\left(120 \mathrm{~kg} \mathrm{~N} \mathrm{ha}^{-1}\right)$ during the maize cycle. Gabriel and Quemada (2011) near Aranjuez (Madrid, Spain), also applying $120 \mathrm{~kg} \mathrm{~N} \mathrm{ha}^{-1}$ at the time of maize sowing, obtained grain yields between $8.4 \mathrm{Mg} \mathrm{ha}^{-1}$ after spontaneous vegetation and $14.5 \mathrm{Mg} \mathrm{ha}^{-1}$ after the vetch. Also Salmerón et al. (2011), with application of $300 \mathrm{~kg} \mathrm{~N}^{-1}$ to the maize cycle recorded much higher values of DM production (between $11.7 \mathrm{Mg} \mathrm{ha}^{-1}$ after non-legume and $15.7 \mathrm{Mg} \mathrm{ha}^{-1}$ after legumes). It should be noted that in these last three studies, the maize used was a hybrid variety, and that the one used in the present study was a regional, much less productive variety. Also, when analysing the total aerial biomass of maize, the values of the present study (from 3.5 to $9.1 \mathrm{Mg} \mathrm{ha}^{-1}$ ) were lower than those reported in the literature: from 20.7 to $-26.7 \mathrm{Mg} \mathrm{ha}^{-1}$ (Salmerón et al., 2011); from 17.1 to $-25.2 \mathrm{Mg} \mathrm{ha}^{-1}$ (Gabriel and Quemada, 2011); from 9.0 to $20.1 \mathrm{Mg}$ $\mathrm{ha}^{-1}$ (Kramberger et al., 2014). Values similar to those in this study are reported in a previous study by Tonitto et al. (2006), where an average value in maize production of $6.4 \mathrm{Mg} \mathrm{ha}^{-1}$, with a minimum value of $0.6 \mathrm{Mg} \mathrm{ha}^{-1}$ and a maximum value of $13.4 \mathrm{Mg} \mathrm{ha}^{-1}$. For these values only studies where the source of $\mathrm{N}$ was leguminous and where no application of mineral $\mathrm{N}$ was made. Also in a study by Mazzoncini et al. (2008), obtained DM values of aboveground biomass were similar to values reported in the present study (from 4.1 to $-7.4 \mathrm{Mg} \mathrm{ha}{ }^{-1}$ ) for treatments where no mineral fertilizer was applied.

Table 7

Dry matter yield $\left(\mathrm{Mg} \mathrm{ha}^{-1}\right)$ of aboveground biomass of the maize crop during the three years of experiment $(n=4)$.

\begin{tabular}{|c|c|c|c|c|c|c|c|c|c|c|}
\hline & & $\mathrm{R}$ & M & BC & GC & $\mathrm{W}$ & $\mathrm{YL}$ & FS & CC & AC \\
\hline \multirow{2}{*}{$2007 / 2008$} & $1^{\text {st }} \mathrm{SD}$ & $7.4^{\mathrm{ab}}$ & $7.9^{\mathrm{ab}}$ & $7.8^{\mathrm{ab}}$ & $9.1^{\mathrm{a}}$ & $6.1^{\mathrm{ab}}$ & $8.4^{\mathrm{ab}}$ & $5.8^{\mathrm{ab}}$ & $7.4^{\mathrm{ab}}$ & $7.2^{\mathrm{ab}}$ \\
\hline & $2^{\text {nd }} \mathrm{SD}$ & $7.5^{\mathrm{ab}}$ & $6.3^{\mathrm{ab}}$ & $6.0^{\mathrm{ab}}$ & $4.3^{\mathrm{ab}}$ & $5.6^{\mathrm{ab}}$ & $6.1^{\mathrm{ab}}$ & $5.0^{\mathrm{ab}}$ & $5.7^{\mathrm{ab}}$ & $6.1^{\mathrm{ab}}$ \\
\hline $2008 / 2009$ & $1^{\text {st }} \mathrm{SD}$ & $4.5^{\mathrm{ab}}$ & $7.3^{\mathrm{ab}}$ & $7.3^{\mathrm{ab}}$ & $6.3^{\mathrm{ab}}$ & $3.6^{\mathrm{b}}$ & $6.4^{\mathrm{ab}}$ & $5.3^{\mathrm{ab}}$ & $7.0^{\mathrm{ab}}$ & $6.9^{\mathrm{ab}}$ \\
\hline \multirow{2}{*}{$2011 / 2012$} & $1^{\text {st }} \mathrm{SD}$ & $6.4^{\mathrm{ab}}$ & $3.3^{\mathrm{b}}$ & $4.2^{\mathrm{ab}}$ & $4.2^{\mathrm{ab}}$ & $4.5^{\mathrm{ab}}$ & $4.8^{\mathrm{ab}}$ & $5.4^{\mathrm{ab}}$ & $3.5^{\mathrm{b}}$ & $5.0^{\mathrm{ab}}$ \\
\hline & $2^{\text {nd }} \mathrm{SD}$ & $3.3^{\mathrm{b}}$ & $3.9^{\mathrm{ab}}$ & $5.2^{\mathrm{ab}}$ & $4.8^{\mathrm{ab}}$ & $4.1^{\mathrm{ab}}$ & $4.6^{\mathrm{ab}}$ & $6.1^{\mathrm{ab}}$ & $4.5^{\mathrm{ab}}$ & $4.4^{\mathrm{ab}}$ \\
\hline
\end{tabular}

R: Ryegrass, M: Mixture of ryegrass and balansa clover, BC: Balansa clover, GC: Gland clover, W: Weeds, YL: Yellow lupin, FS: French serradella, CC: Crimson clover, AC: Arrowleaf clover.

Treatments followed by different letter are significantly different at $p<0.05$ by Bonferroni's test. 


\section{7/08}

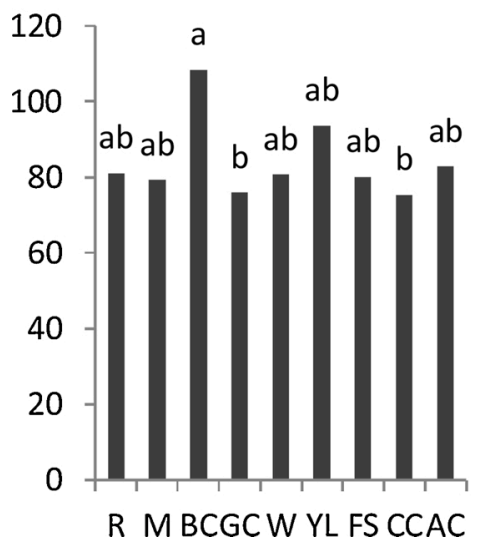

2008/09

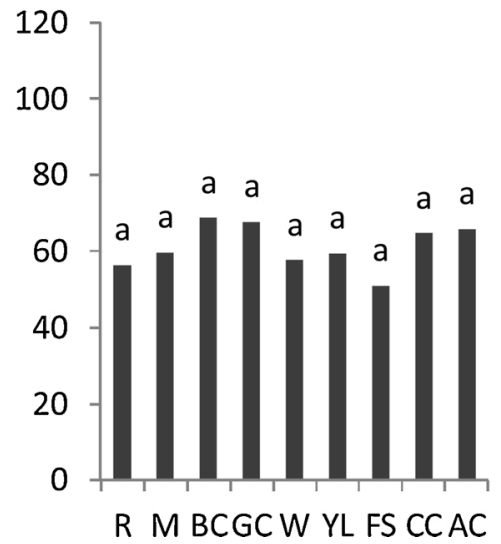

\section{1/12}

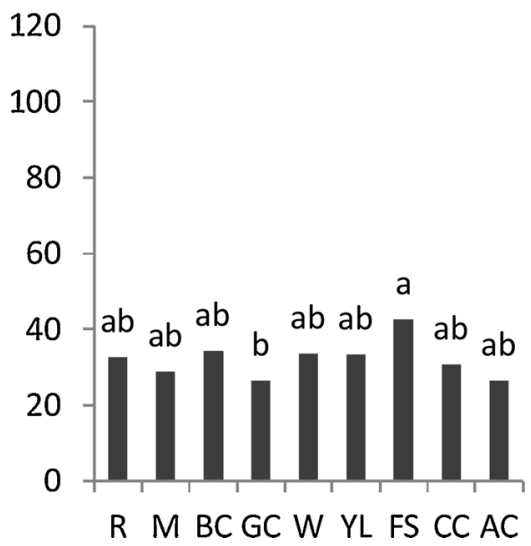

Fig. 2. Effects of year and cover crop interaction in \% critical N concentration. R: Ryegrass, M: Mixture of ryegrass and balansa clover, BC: Balansa clover, GC: Gland clover, W: Weeds, YL: Yellow lupin, FS: French serradella, CC: Crimson clover, AC: Arrowleaf clover. For each year columns followed by different letter are significantly different at $p<0.05$ by Bonferroni's test $(n=4)$.

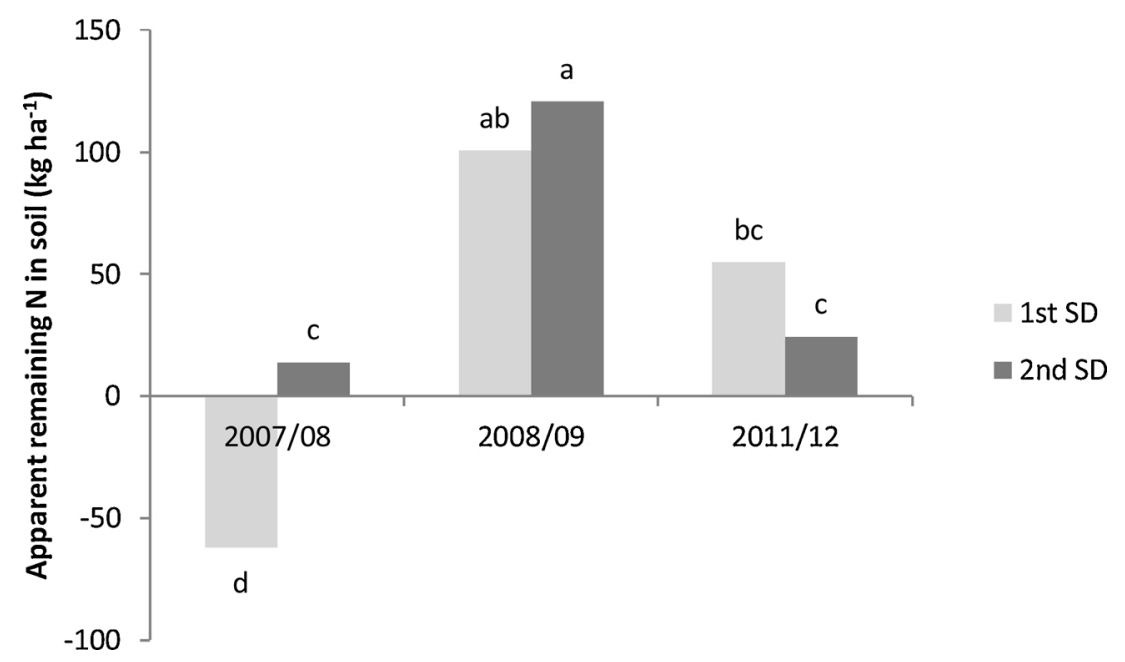

Fig. 3. Effects of year and sowing date interaction in apparent remaining $\mathrm{N}$ in the soil at the end of maize. Columns followed by different letter are significantly different at $p<0.05$ by Bonferroni's test $(n=4)$.

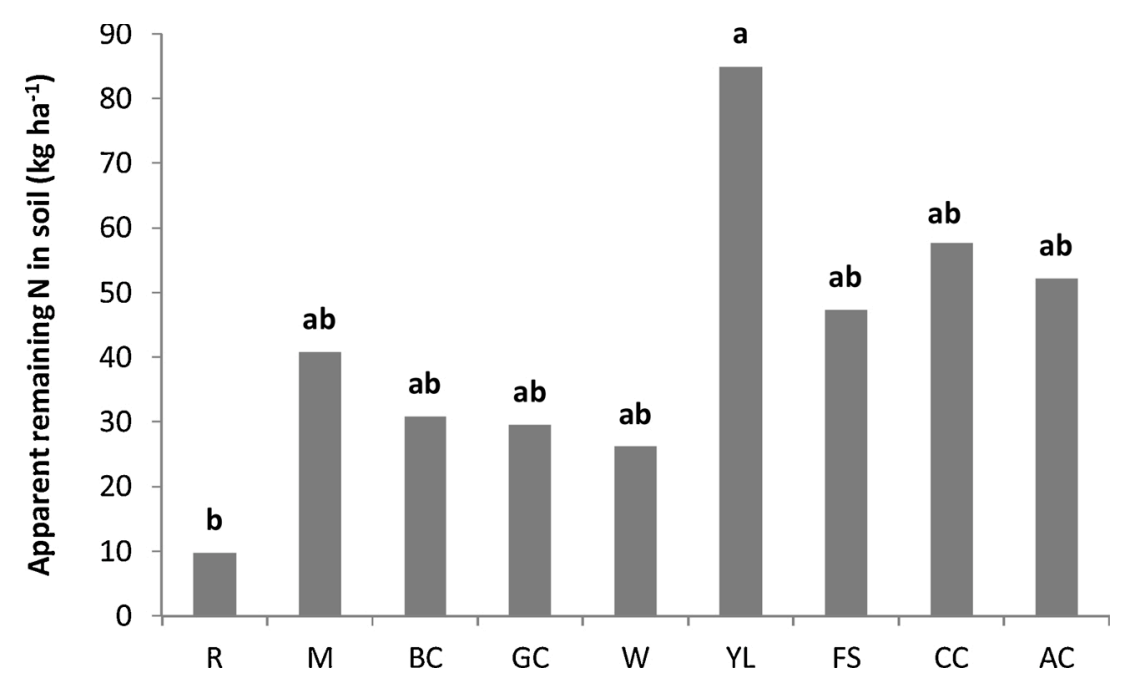

Fig. 4. Apparent remaining $N$ the soil at the harvest of the maize crop. R: Ryegrass, M: Mixture of ryegrass and balansa clover, BC: Balansa clover, GC: Gland clover, W: Weeds, YL: Yellow lupin, FS: French serradella, CC: Crimson clover, AC: Arrowleaf clover. Treatments followed by different letter are significantly different at $p<0.05$ by Bonferroni's test $(n=4)$. 
The highest $\mathrm{N}$ uptake values in the aboveground biomass and grain recorded in the balansa clover and yellow lupin treatments and the lowest values for the ryegrass treatment are in agreement with previous studies (Hanly and Gregg, 2004; Salmerón et al., 2011; Kramberger et al., 2014). These results are explained by the legumes ability to fix atmospheric $\mathrm{N}$ and the subsequent $\mathrm{N}$ enrichment of the soil. This capacity resulted in higher $\mathrm{N}$ availability for maize compared to ryegrass and mixture.

In environmental terms, an efficient use of $\mathrm{N}$ in rotation is an efficient exploitation of all available $\mathrm{N}$ (Kramberger et al., 2014). In the present study, we found a positive $\mathrm{N}$ balance in the soil, although $\mathrm{N}$ was not enough to fill the critical amount of $\mathrm{N}$, allowing us to conclude that $\mathrm{N}$ mineralization may not be synchronized with maize needs, resulting in a deficit of $\mathrm{N}$ to the maize, yet mineral $\mathrm{N}$ remaining at the end of the culture. Positive values in soil $\mathrm{N}$ balance indicate the possibility of positive effects of these treatments on later crops (Kramberger et al., 2014), because available $\mathrm{N}$ is left in the soil for the next crop. This available $\mathrm{N}$ at the end of the cash crop cycle can have negative effects, if the next crop is undemanding in $\mathrm{N}$, if the soil is bare or if there is intense rainfall, for this $\mathrm{N}$ is prone to be lost by leaching. Nitrogen leaching from agricultural soils is of great concern in environmental sustainability due to its input to excess nitrate in ground water (Abdalla et al., 2019). Studies developed (Salazar et al., 2019) found that inclusion of grass cover crops resulted in lower $\mathrm{N}$ losses during maize cultivation and Hively et al. (2020) and Thapa et al. (2018) affirm that non-leguminous cover crops have a high efficiency in reducing nitrate losses.

Kramberger et al. (2014) reported the association between high soil $\mathrm{N}$ balance values, low maize yields and low $\mathrm{N}$ uptake values in maize. In this study, the opposite was true, because it was in the treatments where the highest yields were obtained that we had the highest accumulated $\mathrm{N}$ values, the highest values in the soil $\mathrm{N}$ balance and also the highest $\%$ CNc supplied to the main crop, like in a study developed by (Preza-Fontes et al., 2020). These results evidence the positive effects of cover crops in supply $\mathrm{N}$ to succeeding crop.

Komainda et al. (2016) observed that to get a better $\mathrm{N}$ uptake by cover crops (rye) a sowing date in second decade of September is required. Akbari et al. (2019) affirm that early SD of cover crops gave the highest $\mathrm{DM}$ and $\mathrm{N}$ accumulation and delaying SD from early-September to mid-October suppressed cover crops DM about $40 \%$. In our experiment SD did not induce differences in $\mathrm{N}$ uptake by cover crops perhaps due to the late emergence of cover crops from the first sowing date and slow development due to lack of water in the soil.

In maize, sowing date affected DM and $\mathrm{N}$ uptake of grain and DM of total aboveground biomass. The early SD of cover crops induced an increase in DM production (grain and total aboveground biomass), by grain N uptake increased in treatments from second SD. Van Eerd (2018) observed that sowing date of cover crops does not influence DM and $\mathrm{N}$ uptake of main crops.

There are several studies (Sainju et al., 2006; Möller et al., 2008; Brennan et al., 2011; Kramberger et al., 2013) that indicate that, from an ecological point of view, legume/non-legume mixtures are more advantageous when compared to the standalone components. In this study, mixture, compared to balansa clover, provided about $20 \%$ less $\mathrm{N}$ of CNc and had a soil $\mathrm{N}$ balance about $86 \%$ higher, which makes this treatment was less efficient in providing $\mathrm{N}$ to the main crop when compared to the balansa clover. In mixture, balansa clover made up about $50 \%$ of total aboveground biomass of the mixture. Also Kramberger et al. (2014) found no benefit in the use of blends compared to legume on its own.

With regard to the observed maize production (DM production, $\mathrm{N}$ uptake), the mixture generally presented intermediate values between balansa clover and ryegrass. The effect of mixture on main crop production is reported in different ways: sometimes there are no significant differences $(p>0.05)$ between mixture and the stand-alone crops and sometimes less than leguminous crops or higher than non-legume (Clark et al., 1997; Vaughan et al., 2000; Kuo and Jellum, 2002; Hanly and Gregg, 2004; Ćupina et al., 2011). Generally, the mixture did not present significant differences $(p>0.05)$ with the cover crops used in this study.

When we observe the proportion of CNc that is satisfied by cover crops, we find that they do not provide all $\mathrm{N}$ that the main crop needs, but they do provide a large part, which may justify the application of synthetic fertilizers at moderate doses or, in organic farming, reduce production losses associated with serious deficiencies of $\mathrm{N}$. Therefore, it is necessary to develop measures to quantify the required mineral $\mathrm{N}$. Nitrogen fertilization recommendations for maize can not only be based on $\mathrm{N}$ uptake by cover crops and soil mineral $\mathrm{N}$ at sowing date, but also take into account cover crops quality and climatic conditions. These parameters into account may lead to some difficulties in field conditions (Salmerón et al., 2011), that possibly overcome by close management of soil and/or plant $\mathrm{N}$ mineral content, especially during the most intense growing season. As expected, the value of soil $\mathrm{N}$ balance was higher in legumes compared to non-legumes. Thorup-Kristensen et al. (2003) reported that knowledge of $\mathrm{N}$ dynamics helps to explain the response of maize to the effect of previous cover crops.

\section{Conclusion}

In Mediterranean environment, winter cover crops were efficient and recommended as $\mathrm{N}$ source for maize crop. The different effect between crops was not felt in the production of DM by maize, where only the variables years and date of sowing had globally significant effects. The aboveground biomass of maize presented higher DM production when cover crops were installed in early sowing date. Sowing dates influenced the $\mathrm{N}$ uptake value and it was the treatments related to early sowing that induced the highest $\mathrm{N}$ uptake value.

The cover crop species revealed their importance in the maize $\mathrm{N}$ uptake value, in general, it was the treatment related to the balansa clover that had the highest $\mathrm{N}$ uptake and it was also the balansa clover treatment that satisfied a larger proportion of the critical $\mathrm{N}$ concentration (about $70 \%$ ). Regarding the efficiency of depleting the soil mineral $\mathrm{N}$ until the end of the maize crop cycle, values for ryegrass were the lowest, but only significantly lower than lupin.

Yellow lupin was the treatment which left the largest amount of mineral $\mathrm{N}$ in the soil at the end of the maize crop, immediately before the period of risk of leaching.

Future research should advance the understanding of the mechanisms underlying cover crop effects on crop productivity because these will have important repercussion for sustainable agriculture and understanding the long-term consequences of including cover crops in Mediterranean cropping systems.

\section{CRediT authorship contribution statement}

Adelaide Perdigão: Investigation; Data curation, Roles/Writing original draft. José Pereira: Reviewing draft. Nuno Moreira: Conceptualization, Methodology. Henrique Trindade: Supervision, Formal analysis. João Coutinho: Methodology, Supervision, Formal analysis.

\section{Declaration of Competing Interest}

The authors report no declarations of interest.

\section{Acknowledgements}

This research was funded by National Funds by FCT - Portuguese Foundation for Science and Technology, under the project UIDB/04033/ 2020 and UIDB/00681/2020. Adelaide Perdigão has received a grant from the FCT (SFRH/BD/69105/2010). The authors thank the Editor and Reviewers for their comments and constructive suggestions. 


\section{References}

Abdalla, M., Hastings, A., Cheng, K., Yue, Q., Chadwick, D., Espenberg, M., Truu, J., Rees, R.M., Smith, P., 2019. A critical review of the impacts of cover crops on nitrogen leaching, net greenhouse gas balance and crop productivity. Glob. Chang. Biol. 25, 2530-2543.

Akbari, P., Herbert, S.J., Hashemi, M., Barker, A.V., Zandvakili, O.R., 2019. Role of cover crops and planting dates for improved weed suppression and nitrogen recovery in No till systems. Commun. Soil Sci. Plant Anal. 50, 1722-1731.

Alonso-Ayuso, M., Quemada, M., Vanclooster, M., Ruiz-Ramos, M., Rodriguez, A., Gabriel, J.L., 2018. Assessing cover crop management under actual and climate change conditions. Sci. Total Environ. 621, 1330-1341.

Breda, F.A.F., Alves, G.C., Lopez, B.D.O., Aragão, A.R., Adelson Paulo, Araújo, A.P., Reis, V.M., 2020. Inoculation of diazotrophic bacteria modifies the growth rate and grain yield of maize at different levels of nitrogen supply. Arch. Agron. Soil Sci. 66, 1948-1962.

Brennan, E.B., Boyd, N.C., Smith, R.F., Foster, P., 2011. Comparison of rye and legumerye cover crop mixtures for vegetable production in California. Agron. J. 103, 449-463.

Ciampitti, I.A., Vyn, T.J., 2014. Understanding global and historical nutrient use efficiencies for closing maize yield gaps. Agron. J. 106, 2107-2117.

Clark, A.J., Decker, A.M., Meisinger, J.J., McIntosh, M.S., 1997. Kill date of hairy vetch, rye and vetch/rye mixture. I. Cover crops and corn nitrogen. Agron. J. 89, 427-434.

Ćupina, B., Manojlović, M., Kristić, Dj., Čabilovski, R., Mikić, A., Ignjatović-Ćupina, A., Erić, P., 2011. Effect of winter cover crops on the dynamics of soil mineral nitrogen and yield and quality of Sudan grass [Sorghum bicolor (L.) Moench]. Aust. J. Crop Sci. 5 (7), 839-845.

da Silva, E.C., Muraoka, T., Bastos, A.V.S., Franzini, V.I., da Silva, A., Buzetti, S., Sakadevan, K., Soares, F.A.L., Teixeira, M.B., Trivelin, P.C.O., de Araujo, L.C., 2020 Nitrogen recovery from fertilizers and cover crops by maize crop under no-tillage system. Aust. J. Crop Sci. 14, 766.

Fan, X., Vrieling, A., Muller, B., Nelson, A., 2020. Winter cover crops in Dutch maize fields: variability in quality and its drivers assessed from multi-temporal Sentinel-2 imagery. Int. J. Appl. Earth Obs. Geoinf. 91, 102139.

Gabriel, J., Quemada, M., 2011. Replacing bare fallow with cover crops in a maize cropping system: yield, N uptake and fertiliser fate. Eur. J. Agron. 34, 133-143.

Hanly, J.A., Gregg, P.E.H., 2004. Green-manure impacts on nitrogen availability to organic sweetcorn (Zea mays). N. Z. J. Crop Hortic. Sci. 32, 295-307.

Hively, W.D., Lee, S., Sadeghi, A.M., McCarty, G.W., Lamb, B.T., Soroka, A., Keppler, J., Yeo, I.-Y., Moglen, G.E., 2020. Estimating the effect of winter cover crops on nitrogen leaching using cost-share enrollment data, satellite remote sensing, and Soil and Water Assessment Tool (SWAT) modeling. J. Soil Water Conserv. 75, 362-375.

IUSS Working Group W.R.B, 2006. World reference Base for soil resources. World Soil Resources Reports 103, 2nd edition. FAO, Rome.

Kaye, J.P., Quemada, M., 2017. Using cover crops to mitigate and adapt to climate change. A review. Agron. Sustain. Dev. 37, 4.

Komainda, M., Taube, F., Kluß, C., Herrmann, A., 2016. Above- and belowground nitrogen uptake of winter catch crops sown after silage maize as affected by sowing date. Eur. J. Agron. 79, 31-42.

Kramberger, B., Gselman, A., Janzekovic, M., Kaligaric, M., Bracko, B., 2009. Effects of cover crops on soil mineral nitrogen and on the yield and nitrogen content of maize. Eur. J. Agron. 31, 103-109.

Kramberger, B., Gselman, A., Podvršnik, M., Kristl, J., Lešnik, M., 2013. Environmental advantages of binary mixtures of Trifolium incarnatum and Lolium multiflorum over individual pure stands. Plant Soil Environ. 59, 22-28.

Kramberger, B., Gselman, A., Kristl, J., Lešnik, M., Šuštar, V., Muršec, M., Podvršnik, M., 2014. Winter cover crop: the effects of grass-clover mixture proportion and biomass management on maize and the apparent residual N in the soil. Eur. J. Agron. 55, 63-71.

Kuo, S., Jellum, E.J., 2002. Influence of winter cover crop and residue management on soil nitrogen availability and corn. Agron. J. 94, 501-508.

Lemaire, G., Recous, S., Mary, B., 2004. Managing residues and nitrogen in intensive cropping systems. New understanding for efficient recovery by crops. In:
Proceedings of $4{ }^{\text {Th }}$ International Crop Science Congress, 26 Sept- $1^{\text {st }}$ October 2004. Brisbane, Australia.

Marcillo, G.S., Carlson, S., Filbert, M., Kaspar, T., Plastina, A., Miguez, F.E., 2019. Maize system impacts of cover crop management decisions: a simulation analysis of rye biomass response to planting populations in Iowa. U.S.A. Agric. Syst. 176, 102651.

Mazzoncini, M., Migliorini, P., Antichi, D., Vazzana, C., 2008. Effects of green-manure and organic fertilizer on organic maize (Zea Mays L.) in south tuscany. In: Proceedings of the ISOFAR International Scientific Conference, 16th IFOAM Organic World Congress. Modena, Italy. Modena. June 16-20 2008,vol.1,p.199-202, ISOFAR, ISBN: 978-3-03736-023-1.

Möller, K., Stinner, W., Leithold, G., 2008. Growth, composition, biological N $\mathrm{N}_{2}$ fixation and nutrient uptake of a leguminous cover crop mixture and the effect of their removal on field nitrogen balances and nitrate leaching risk. Nutr. Cycl. Agroecosystems 82, 233-249.

Perdigão, A., Coutinho, J., Moreira, N., 2012. Cover crops as nitrogen source for organic farming in Southwest Europe. Acta. Hortic. 933, 355-361.

Preza-Fontes, G., Nafziger, E.D., Christianson, L.E., Pittelkow, C.M., 2020. Relationship of in-season soil nitrogen concentration with corn yield and potential nitrogen losses. Soil Sci. Soc. Am. J. 84, 1296-1306.

Rasmussen, J., Søegaard, K., Pirhofer-Walzl, K., Eriksen, J., 2012. $\mathrm{N}_{2}$-fixation and residual $\mathrm{N}$ effect of four legume species and four companion grass species. Eur. J. Agron. 36, 66-74.

Raza, S., Chen, Z., Ahmed, M., Afzal, M.R., Aziz, T., Zhou, J., 2019. Dicyandiamide application improved nitrogen use efficiency and decreased nitrogen losses in wheatmaize crop rotation in Loess Plateau. Arch. Agron. Soil Sci. 65 (4), 450-464.

Rose, T.J., Kearney, L.J., Erler, D.V., Zwieten, L., 2019. Integration and potential nitrogen contributions of green manure inter-row legumes in coppiced tree cropping systems. Eur. J. Agron. 103, 47-53.

Sainju, U.M., Whitehead, W.F., Sing, B.P., Wang, S., 2006. Tillage, cover crops, and nitrogen fertilization effects on soil nitrogen and cotton and sorghum yields. Eur. J. Agron. 25, 372-382.

Salazar, O., Balboa, L., Peralta, K., Rossi, M., Casanova, M., Tapia, Y., Singh, R., Quemada, M., 2019. Effect of cover crops on leaching of dissolved organic nitrogen and carbon in a maize-cover crop rotation in Mediterranean Central Chile. Agric. Water Manage. 212, 399-406.

Salmerón, M., Isla, R., Cavero, J., 2011. Effect of winter cover crop species and planting methods on maize yield and $\mathrm{N}$ availability under irrigated Mediterranean conditions. Field Crops Res. 123, 89-99.

Sandhu, O.S., Gupta, R., Thind, H.S., Jat, M.L., Singh, Y.-, Sidhu, H.S., 2019. Evaluation of $\mathrm{N}$ fertilization management strategies for increasing crop yields and nitrogen use efficiency in furrow-irrigated maize-wheat system under permanent raised bed planting. Arch. Agron. Soil Sci. 66, 1302-1317.

Setiyono, T.D., Yang, H., Walters, D.T., Dobermann, A., Ferguson, R.B., Roberts, D.F., Lyon, D.J., Clay, D.E., Cassman, K.G., 2011. Maize-N: a decision tool for nitrogen management in maize. Agron. J. 103 (4), 1276-1283.

Soti, P., Racelis, A., 2020. Cover crops for weed suppression in organic vegetable systems in semiarid subtropical Texas. Org. Agric. 10, 429-436.

Thapa, R., Mirsky, S.B., Tully, K.L., 2018. Cover crops reduce nitrate leaching in agroecosystems: a global meta-analysis. J. Environ. Qual. 47, 1400-1411.

Thorup-Kristensen, K., Magid, J., Jensen, L.S., 2003. Catch crops and green manures as biological tools in nitrogen management in temperate zones. Adv. Agr. 79, 227-302.

Tonitto, C., David, M.B., Drinkwater, L.E., 2006. Replacing bare fallows with cover crops in fertilizer-intensive cropping systems: a meta-analysis of crop yield and $\mathrm{N}$ dynamics. Agric. Ecosyst. Environ. 112, 58-72.

Van Eerd, L.L., 2018. Nitrogen dynamics and yields of fresh bean and sweet corn with different cover crops and planting dates. Nutr. Cycl. Agroecosyst. 111, 33-46.

Vaughan, J.D., Hoyt, G.D., Wollum I.I., A.G., 2000. Cover crop nitrogen availability to conventional and no-till corn: soil mineral nitrogen, corn nitrogen status, and corn yield. Commun. Soil Sci. Plant Anal. 31, 1017-1041.

Yeganehpoor, F., Salmasi, S.Z., Abedi, G., Samadiyan, F., Beyginya, V., 2015. Effects of cover crops and weed management on corn yield. J. Saudi Soc. Agric. Sci. 14 (2), $178-181$. 